\title{
Entry and Exit of Nonprofit Organizations
}

\section{National, Sectorial, and Geographic Trends with Italian Census Data}

\author{
${ }^{1}$ Università Cattolica del Sacro Cuore, Department of Economics and Finance, Largo Cemelli, 120123 Milano, Italy, E-mail: \\ gianpaolo.barbetta@unicatt.it. http://orcid.org/0000-0001-5865-3766. \\ ${ }^{2}$ Fondazione Cariplo Evaluation Unit, Via Manin, 23, 20123 Milano, Italy \\ ${ }^{3}$ Istat, Sede territoriale Lombardia, Via Porlezza, 1220123 Milano, Italy
}

\begin{abstract}
:
The latest census of Italian nonprofit organizations - compared with the previous one - showed a significant development of the nonprofit sector between 2001 and 2011. The number of organizations increased more than $28 \%$ while the growth of employees (about $61 \%$ ) was even more impressive.

These results notwithstanding, the mere comparison of aggregate census data does not give a true understanding of the dynamic of the sector. The entry and exit of organizations, as well as their migration between different sectors of activity, or geographical areas, can be analyzed properly only using firm-level panel data, but these data are rarely available so that only a few authors had a chance to use them. In this paper, we try to fill this gap using firm-level panel data for the first time in Italy. Our analysis tempers the optimism arising from aggregate data. We show that: a) part of the growth is determined by the emergence of already active organizations that were not detected a decade ago; b) because of low barriers, the entry of new nonprofit organizations is very relevant, but their net contribution to the growth of employment is quite small; c) opposite to what happened in other countries, the exit of nonprofit organizations is very significant, and d) organizations that were already active a decade ago gave the most important contribution to the growth of employment. We also investigate geographical trends, showing that the slower growth of the nonprofit sector in Southern Italy depends on the very high exit rate of the area, while the entry rate is more or less in line with the rest of the country.
\end{abstract}

Keywords: entry, exit, nonprofit organizations, census, microdata, Italy

JEL classification: L31, D22

DOI: $10.1515 / \mathrm{npf}-2017-0036$

\section{Introduction}

The latest census of Italian nonprofit organizations (Istat 2014) - when compared with the previous one (Istat 2004) - shows a significant development of the sector between 2001 and 2011. The number of nonprofit organizations (Npos) increased more than $28 \%$. The growth of full-time equivalent employees (Fte) (about $61 \%$ ) and volunteers (about $43 \%$ ) were even more impressive. This result is particularly relevant because, among western countries, Italy used to have one of the smallest nonprofit sector (Anheier and Salamon 2006; Barbetta 1997; Barbetta 2000; Salamon and Anheier 1996). Other countries experienced the same trend of growth. For example, in the USA, the number of tax-exempt Npos registered with the IRS grew from 1.3 million in 2001 to 1.58 million in 2011 (a $22 \%$ growth) while, over the same period, their revenues increased more than $74 \%$ to 2.1 trillion dollars (Pettijohn 2013).

The Italian trend induced observers to depict the growth of the sector as a "success story", while policy makers imagined that - supporting this growth - they could reduce the very high rate of unemployment that afflicts the country ${ }^{1}$. In fact, in 2014, when the new data were released, the Italian government announced the creation of an investment fund, endowed with €500 million, designed for boosting the creation of new social enterprises and Npos; moreover, in 2016, the Italian Parliament passed a new regulatory frame, aimed at better supporting the sector (but reduced the fund to no more than $€ 50$ million).

This enthusiasm notwithstanding, the comparison of aggregate data does not give a clear understanding of the real dynamic that characterized the sector over that period. In particular, entry and exit of organizations, as well as their migration between different sectors of activity, or geographical areas, cannot be precisely detected. These trends can only be grasped using panel data of individual entities. 
When firm-level panel data of Npos are used, as we make in this paper, the growth of the Italian nonprofit sector over the decade becomes much less impressive. In fact, about two thirds of the growth in the number of Npos, and one third of the growth in Fte, can be attributed to the improved detection methods adopted by the Italian statistical office. These methods allowed, in year 2011, to identify Npos that already existed in year 2001, but where not spotted at that time. The use of panel date allowed us to detect this event.

Moreover, panel data could help studying the entry and exit dynamic of Npos, but so far "the entry and exit patterns of charitable organizations have not been studied, and represent a potentially fertile area of research" (List 2011). Only a few studies analyzed these events. Most of them adopted a theoretical approach, focusing on the demand and supply conditions that could lead to the entry (or exit) of Npos into specific markets, while paying attention to how public or private attitudes (such as public spending on social services, or private donations) could affect the number of existing organizations (Rose-Ackerman 1982; Schiff and Weisbrod 1993). These studies are deeply rooted into the different competing theories explaining the origins of the nonprofit sector, such as the "contract failure" (Hansmann 1980, 1987), the "government failure and heterogeneous demand" (Weisbrod 1977; James and Rose-Ackerman 1986; Young 2000a), and the "social origin" theories (Salamon and Anheier 1998). Recent comparative studies gave a qualitative description of the role played by public welfare in supporting the growth of new Npos, embracing the "social origin" theory. For example, Archambault, Priller, and Zimmer (2014), focusing on France and Germany, underlined that "[t]he embracement of the sector by the welfare state resulted in both countries in a success-story as well as a remarkable growth of nonprofit organizations" (p. 520). In a similar way, Casey (2016), after describing the different sources of data that allow to compare the growth of Npos in different countries, observes "a common international trend toward an increased capacity of the population for independent organizing and action, changing public expectations of the role of nonprofits, a policy shift to governance and partnership approaches that involve third-party arrangements" (p. 218).

The main limit of these studies is their little empirical base. Other authors tried to test empirically the relevance of the different theories by correlating the weight of the nonprofit sector (or its density, or growth over time) - in specific sectors, countries or cross-nationally - to various set of explanatory variables. For example, Corbin (1999) used cross-sectional data and correlated the number of Npos acting in 285 metropolitan areas in the USA with measures derived from social cohesion, demand heterogeneity, market failure, resource dependence, and philanthropic culture theories, but his findings were not conclusive. Similarly, Twombly (Twombly 2002,2003 ) adopted an approach based on the theory of population ecology to describe the environmental and organizational factors correlated to the entry and exit of human service nonprofits. On a more limited base, Andersson and Ford (2016) analyzed the emergence of voucher schools in Milwaukee, Wisconsin. On a larger comparative scale, Salamon, Sokolowki, and Anheier (2000) used country level cross-sectional data to develop and test the "social origin" theory.

To overcome the limits of cross-sectional studies, Matsunaga and Yamauchi (2004) used US state-level panel data to test the "government failure" theory and showed "findings which indicate that observable demand heterogeneity has a positive effect on the size of the nonprofit sector" (p. 227). On the same pattern, Lecy and Van Slyke (2013) used panel data of 331 metropolitan areas in the USA for the period 1998-2003 to test the relevance of the "government failure" and the "social origin" theories and found support for the latter. Recently, Dietz et al. (2017) compared performance of Npos in different states with the regulatory breadth of the state itself.

While based on a sounder empirical base, these papers are mainly focused at testing general theories, but their description and interpretation of the specific behavior of Npos is quite limited. A most notable exception is represented by Harrison and Laincz (2008); the authors use firm-level panel data to describe the entry and exit pattern of Npos in the US economy ${ }^{2}$. They find that new-born Npos behave similarly to their for-profit counterparts, as they start smaller but grow faster than the industry average. On the contrary, the exit patterns are very different as nonprofit show a low exit rates and the "survival rate of new nonprofit firms greatly exceeds those found in studies on services and manufacturing" (p. 1). In a further study Harrison and Thornton (2014) show that - in the years 1990-2005 - the rapid increase in the number of Npos goes hand in hand with a decrease in nonprofit density determined by growth in population and income, as well as by changes in technologies that allow each firm to serve a larger amount of people. More recently, Gayle, Harrison, and Thornton (2017) analyzed the entry patterns of donative nonprofit organizations in five US industries and described the level of competition in those fields. Coherently with the model of competition among charitable organizations proposed by Rose-Ackerman (1982), the authors observe what could be interpreted as "excess" entry into the sector. As far as we are aware, no similar studies can be found outside the USA.

In this paper, we try to add to this limited body of literature using firm-level census panel data to describe the entry and exit trends of the Italian Npos between 2001 and 2011. To our knowledge, this is the first description of the demographic trends of Italian Npos, and one of the very few available for nonprofit entities worldwide. We focus our attention on the creation of new organizations. Our analysis tempers the optimism arising from 
the mere reading of Italian aggregate data. We underline that - besides favoring the creation of new Npos policy makers should pay attention to entities that are already active: in fact, these organizations gave the most relevant contribution to the sectorial growth in employment. This is far from the widespread rhetoric about new job positions created by new social enterprises (Oecd 2013).

The paper continues as follows. Section 2 describes the main features of the Italian nonprofit sector; Section 3 concentrates on our database; Section 4 describes our method of analyses and refers the most relevant result, while Section 5 draws some preliminary conclusions.

\section{The Italian Nonprofit Sector}

At the end of last century, the Italian nonprofit sector emerged as one of the less developed among Western countries, as it was shown by the Johns Hopkins Comparative Nonprofit Sector Project (Barbetta 1997; Salamon and Anheier 1996; Anheier and Salamon 2006; Anheier and Seibel 2001; Archambault 1997; Kendall and Knapp 1996; Kuti 1996; Wijkstrom and Lundstrom 1997; Yamamoto 1998). Several reasons could explain the "Italian difference": the legacy of the nineteenth century fight between the State and the catholic church, when the country was unified, that reduced to the role of catholic civil society organizations; a lay tradition of civic engagement and advocacy that lobbied for public provision of services and did not develop into commercial nonprofit organizations; the very relevant role of direct public sector provision in the fields of education, health and residential social services; the role of families as providers of light educational and social services to their members; the very small number of grant-making foundations that could sustain the growth of Npos, just to mention the most relevant ones.

At the very end of last century, when Istat (the Italian statistical office) started official data collections in the field, the nonprofit sector showed a clear tendency to growth (Istat 2001 2004), and the trend increased in the first decade of the new century (Istat 2014). In less than two decades, Italian Npos developed their activities in several areas, and contributed to the creation of quite a large sector of the economy. In 2014, when the latest census data was released, the Italian nonprofit sector showed a new face: the number of Npos went up from 235 thousand in 2001 to more than 300 thousand in 2011, while the number of Fte grew from less than 600 thousand to about 1 million, over the same period.

The spectacular growth in the work force of the sector goes hand in hand with the increase in the number of social enterprises, notably social cooperatives. In fact, social cooperatives were the most dynamic component of the sector over the last decade. Their number almost doubled, going from about 5,600 in 2001 to more than 11,000 in 2011, and the same happened with their labor force that increased from 149 thousand to about 301 thousand people (Thomas 2004; Galera and Borzaga 2009). The growth of the more entrepreneurial part of the Npos. In fact, while the growth of the Italian welfare system in the Seventies and the Eighties brought about the development of public service delivery, in the Nineties a new trend toward contracting-out (or complete assignment) of service provision to Npos emerged. This tendency could be attributed to a couple of factors. First, the increasing difficulties experienced by the public budget and the consequent attempt to rely on less expensive private service providers. Second, the problems suffered by public suppliers in providing services that could answer the new needs arising from a more and more diversified population. More flexible nonprofit entities were identified as a possible answer. This "marketization" of the Italian public welfare reflects what happened in other countries characterized by strong public provision of welfare services, such as the Nordic ones (Sivesind et al. 2002; 2011). Moreover, because of the overall public budget retrenchment, the private request for welfare services increased, and Npos (especially social cooperatives) were in a good position to take advantage of this new demand. This trend became stronger in the new century, but was already present in the previous one, given that, on average, the largest component of Italian Npos revenues is represented by fees paid by clients. This is coherent with the comparative evidence developed by Anheier (2005).

This change notwithstanding, in 2011, the Italian nonprofit sector keeps its long-term dualistic structure (Barbetta, Mancini, and Lorenzini 2016). Npos are well developed in the Northern and Central parts of the country while they are less active in the South (Figure 1). A relatively small number of very large organizations concentrates most of the work force of the sector, with less than 300 organizations $-0,03 \%$ of the total number - employing about $25 \%$ of Fte. A few areas of activity (health, education and social service) represent more than $70 \%$ of the total work force, while other areas are populated by organizations mainly based on volunteers. Npos (and particularly the large ones) mostly rely on contracts - with public administrations and individuals to fund their activities, while donations still represent a very small fraction (slightly more than $7 \%$ ) of the total revenues of the sector. 
(a)

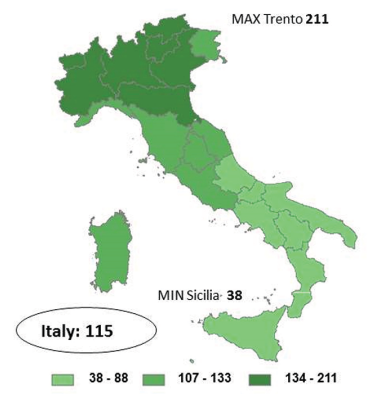

(b)

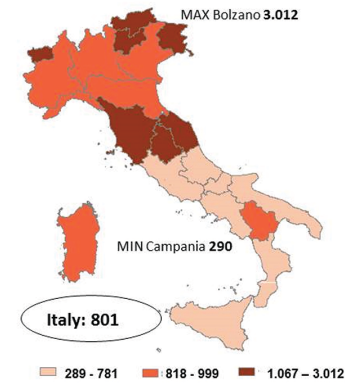

Figure 1: Number of employees (a) and volunteers (b), [per 10,000 people].

\section{Data}

To better appreciate the changes that characterized the nonprofit sector in the last decade, we use firm-level panel data coming from the Italian census. Our dataset was created by pooling together the two independent datasets of the 2001 and 2011 census of Italian Npos (Istat 2004, 2014). It should be considered that the 2001 census of Italian Npos was a pilot approach of the Italian statistical office to the sector. In fact, only in 2011 Istat could rely (for the new census) on a very comprehensive database including the complete list of Italian Npos registered in more than 30 different administrative datasets. Thanks to these datasets, collected over the decade, Istat was able to reach organizations that were not censused a decade before. As we will show in the following paragraph, this generated a much more accurate estimate of the size of the Italian nonprofit sector.

The pooling of the two censuses was made possible by Istat, given that the census micro-data are not normally available for use. Thanks to this new dataset, we were able to identify three kinds of organizations: 1) the organizations active in 2001, but no longer active in the nonprofit sector ten years later ("Ceased or Exit"); 2) the organizations active in 2011, which were not recorded in 2001, and declared to have started their activities after 2001 ("Born or Entry"), and 3) the organizations active in 2011, which were not recorded in 2001, but claimed to have started their activities - with a nonprofit legal status - before 2001 ("Emerged"). The third set of organizations is the result of improved detection techniques adopted by Istat for the latest census, while its size hints at the possible bias of the 2001 measure of the Italian nonprofit sector.

For each organization included in our dataset, we were able to analyze the information recorded by the census questionnaire, such as location, main sector of activity, number of employees, etc.

\section{The Change of the Sector}

\subsection{Change in Organizations}

In Italy, in year 2001, the census recorded 235 thousand Npos, while in 2011 there were more than 301 thousand, with a $28 \%$ growth. In general, one could can say that:

$$
R_{11}=R_{01}+B_{01-11}-C_{01-11}+E_{11}
$$

where:

$\mathrm{R}_{11}=$ Npos recorded in 2011,

$\mathrm{R}_{01}=$ Npos recorded in 2001,

$\mathrm{B}_{01-11}=$ Npos created between 2001 and 2011 ("Born"),

$\mathrm{C}_{01-11}=$ Npos ceased between 2001 and 2011 ("Ceased"),

$\mathrm{E}_{11}=$ Npos recorded only in 2011, but already active in 2001 ("Emerged").

With this identity in mind, and thanks to our dataset, we can describe (Table 1) what happened to the Italian nonprofit sector in the last decade. First, a significant part of the growth in the number of Npos depends on the capacity of the statistical office to identify - in 2011 - organizations that, although active in the field, had not been detected ten years earlier: this happened to about 45 thousand "emerged" entities ${ }^{3}$. Secondly, a large part of the growth of the sector can be attributed to the capacity of the Italian civil society to create new 
organizations: in fact, more than 141 thousand entities were started during this decade. Nonetheless, in the same period, about 121 thousand Npos stopped their activities, or moved to a different sector of the economy. The balance between "entry" and "exit" (the net birth - or the "natural" growth - rate) is therefore positive, with more than 20 thousand units. Nonetheless, its contribution to the overall growth of the sector is lower than the one given by the "emerged organizations". Table 2 shows the same dynamic using growth rates.

Table 1: Entry and exit of nonprofit organizations between 2001 and 2011.

\begin{tabular}{|c|c|c|c|c|}
\hline $\begin{array}{l}R_{11}= \\
\text { Npos in } 2011\end{array}$ & $\begin{array}{l}R_{01}+ \\
\text { Npos in } 2001\end{array}$ & $\begin{array}{l}B_{01-11}- \\
\text { Npos created } \\
\text { between } 2001 \text { and } \\
2011 \\
\text { "Natural" growth }\end{array}$ & $\begin{array}{l}\mathrm{C}_{01-11}+ \\
\text { Npos ceased } \\
\text { between } 2001 \text { and } \\
2011\end{array}$ & $\begin{array}{l}E_{11} \\
\text { Npos active in } 2001 \\
\text { and 2011, but } \\
\text { recorded only in } \\
2011 \\
\text { "Emerged" }\end{array}$ \\
\hline $301.191=$ & $235.232+$ & 141.451 - & $121.159+$ & 45.666 \\
\hline
\end{tabular}

${ }^{1}$ Own calculation on data provided by Istat

Table 2: Sources of growth of the number of nonprofit organizations between 2001 and 2011.

\begin{tabular}{lll}
\hline$\left(R_{11}-R_{01}\right) / R_{01}=$ & $\mathbf{B}_{01-11} / R_{01}-$ & $C_{01-11} / R_{01}+$ \\
Total growth & "Natural" growth & $\begin{array}{l}E_{11} / R_{01} \\
\text { "Emerged" }\end{array}$ \\
\hline $28 \%=$ & $8,6 \%+$ & $19,4 \%$ \\
\hline
\end{tabular}

${ }^{1}$ Own calculation on data provided by Istat

The shape of the Italian nonprofit sector in 2011 is deeply influenced by the extremely high entry and exit rates registered in the previous ten years, so much so that over $47 \%$ of the organizations active in 2011 were created during the last decade. The "turn-over" rate of the industry" is well above $100 \%$.

\subsection{Change in Employment}

The entry and exit of organizations greatly impacted on the employment level of the sector. Considering aggregate data, the number of Fte went up from 593 thousand in 2001 to more than 957 thousand in 2011: a $61 \%$ growth. Using firm-level panel data, we can say that:

$$
\text { Fte }_{11} \mid R_{11}=\text { Fte }_{01} \mid R_{01}+\Delta \text { Fte }_{01-11} \mid S_{01-11}+\left(F e_{11} \mid B_{01-11}-\text { Fte }_{01} \mid C_{01-11}\right)+\text { Fte }_{11} \mid E_{11},
$$

where:

Fte $_{11} \mid R_{11}=$ Fte (in 2011) of the Npos recorded in 2011,

$\mathrm{Fte}_{01} \mid \mathrm{R}_{01}=$ Fte (in 2001) of the Npos recorded in 2001,

$\Delta$ Fte $_{01-11} \mid S_{01-11}=$ growth in Fte (between 2001 and 2011) of the Npos recorded in both years ("internal growth")

Fte $_{11} \mid \mathrm{B}_{01-11}=$ Fte (in 2011) of the Npos created between 2001 and 2011,

Fte $_{01} \mid \mathrm{C}_{01-11}=$ Fte (in 2001) of the Npos ceased between 2001 and 2011,

Fte $_{11} \mid E_{11}=$ Fte (in 2011) of the Npos recorded only in 2011, but already existing in 2001 ("emerged").

This identity shows that the growth of the employment level of Npos between 2001 and 2011 is the result of four different dynamics that affected the sector: a) the "internal growth" of those organizations that survived the entire decade, $b$ ) the new job positions generated by organizations that started their activities during this decade, c) the loss of jobs generated by organizations that left the sector, and finally d) the jobs of the "emerged" organizations.

Table 3 shows that the growth in the employment level of organizations already active in 2001 ("internal growth") is very significant, as these entities hired more than 185 thousand new Fte in ten years. By comparison, the net balance between the organizations that entered and those that left the sector (about 68 thousand Fte) is much lower. Besides the former components, the "emerged" organizations added more than 110 thousand jobs to the count of total employment in 2011. We do not exactly know how many of these employees were already 
active in 2001, but one could assume that the average rate of growth for the "emerged" organizations should not differ from the "internal growth" rate of the organizations that survived the whole period, described above.

Table 3: Employees of nonprofit organizations between 2001 and 2011.

\begin{tabular}{|c|c|c|c|c|}
\hline Fte $_{11} \mid R_{11}=$ & $\mathrm{Fte}_{01} \mid \mathrm{R}_{01}+$ & $\begin{array}{l}\Delta \text { Fte }_{01-11} \mid \mathrm{S}_{01-11} \\
+\end{array}$ & Fte $_{11} \mid B_{01-11-}$ & Fte $_{11} \mid E_{11}$ \\
\hline Fte in 2011 & Fte in 2001 & $\begin{array}{l}\text { "Internal } \\
\text { growth" }\end{array}$ & "Natural" growth & "Emerged" \\
\hline $957.124=$ & $592.791+$ & $185.279+$ & $234.508-165.846+$ & 110.392 \\
\hline
\end{tabular}

${ }^{1}$ Own calculations on data provided by Istat

Considering rates of growth, rather than absolute values (Table 4), we note that about half of the increase in jobs is generated by the organizations already active at the beginning of the period. Contrarily, only about one-fifth of that increase can be attributed to the net balance of entry and exit. The role of the Npos the entered the sector is not at all modest when new employment is considered, as they generated about a quarter of total industry employment in 2011. However, this positive contribution to the growth of total employment is partially offset by the loss of jobs caused by the organizations that left the market.

Table 4: Sources of growth of employment in nonprofit organizations between 2001 and 2011.

\begin{tabular}{llll}
\hline $\begin{array}{l}\text { Total growth of Fte } \\
\text { 2001-2011 }\end{array}$ & "Internal growth" & "Natural" growth & "Emerged" \\
\hline $61,5 \%=$ & $\mathbf{3 1 , 3} \%+$ & $\mathbf{1 1 , 6 \% +}$ & $\mathbf{1 8 , 6 \%}$ \\
\hline
\end{tabular}

${ }^{1}$ Own calculations on data provided by Istat

The very high entry rate we measured (and the consequent growth in Fte) is coherent with Rose-Ackerman's (1982) argument about low entry barriers that allows ideologically driven entrepreneurs to start new firms, as well as with the evidence produced by Harrison and Laincz (2008) for the USA. In fact, in Italy, creating a new association or a new social cooperative is very easy: a few regulatory requirements must be observed and only a very limited amount of capital is needed. Nonetheless, differently from the USA, the exit rate of Italian Npos is quite high as well. We do not have a strong explanation of this evidence, and further research in this field is certainly needed. Anyway, very simple ratios based on Table 1 and Table 3 show that the Npos that left the industry (with an average size of about 1.4 Fte) were much smaller than those continuing their activities in the field (about 3.3 Fte), than the emerged Npos (about 2.4 Fte), as well of the Npos that entered the sector in the last decade (1.6 Fte). Coherently with Harrison and Laincz (2008), we find that new Npos starting their activities are smaller than the existing ones. Moreover, we find that Npos leaving the industry are, by far, the less developed part of the sector. Most likely these are the organizations that were unable to became fully sustainable. This, of course, has some policy implication: while the government is concentrating on supporting the creation of new Npos, it should also try to address the weaknesses of these organizations, most likely connected to their failure in strategic planning as well as organizational and financial management.

\subsection{Sectorial Change}

When economic activities are examined, we must consider that - between 2001 and 2011 - some Npos moved to a different sector of the economy. In our dataset, the quite relevant sectorial changes of organizations could depend on real changes of activity, or - for organizations undertaking the very same activity - by changes in self-classification. To minimize the problem of time-inconsistent self-classification, we decided to aggregate the various sectors of the ICNPO classification (Salamon and Anheier 1996) into four broad areas: 1) culture, sports and recreation, 2) health and social care, 3) education and research, and 4) advocacy and not elsewhere classified activities (n.e.c.). Therefore, the organizations moving between those four wide areas will be considered as "changing sector of activity" while those moving within those areas will not. We can state that, for each of the four areas:

$$
\mathrm{R}_{11}=\mathrm{R}_{01}+\left(\mathrm{En}_{01-11}-\mathrm{Le}_{01-11}\right)+\left(\mathrm{B}_{01-11}-\mathrm{C}_{01-11}\right)+\mathrm{E}_{11},
$$


where the variables have the meaning specified earlier, and:

$\mathrm{En}_{01-11}=$ Npos entering the area of activity between 2001 and 2011, and always recorded (in two different areas) in the two censuses;

$\mathrm{Le}_{01-11}=$ Npos leaving the area of activity between 2001 and 2011, and always recorded (in two different areas) in the two censuses.

This identity shows that, in each sector of the economy, the number of organizations recorded in 2011 is the sum of the organizations recorded in 2001, plus the "net migration" into the sector, the net growth of organizations, and the number of organizations that emerged thanks to technical improvements in the census. Table 5 and Table 6 describe the role played by the sectorial migration of organizations across different industries.

Table 5: Entry and exit of nonprofit organizations between 2001 and 2011, by area of activity.

\begin{tabular}{|c|c|c|c|c|c|c|c|}
\hline & $\begin{array}{l}R_{11}= \\
\text { Npos in } \\
2011\end{array}$ & $\begin{array}{l}R_{01}+ \\
\text { Npos in } \\
2001\end{array}$ & $\begin{array}{l}\mathrm{En}_{01-11}- \\
\text { Npos } \\
\text { entering } \\
\text { the area } \\
\text { between } \\
2001 \text { and } \\
2011 \\
\text { "Net mig }\end{array}$ & $\begin{array}{l}\text { Le }_{01-11}+ \\
\text { Npos } \\
\text { leaving the } \\
\text { area } \\
\text { between } \\
2001 \text { and } \\
2011 \\
n^{\prime \prime}\end{array}$ & $\begin{array}{l}B_{01-11}- \\
\text { Npos } \\
\text { created } \\
\text { between } \\
2001 \text { and } \\
2011 \\
\text { "Natural" }\end{array}$ & $\begin{array}{l}\mathrm{C}_{01-11}+ \\
\text { Npos } \\
\text { ceased } \\
\text { between } \\
2001 \text { and } \\
2011 \\
\text { wth }\end{array}$ & $\begin{array}{l}\mathrm{E}_{11} \\
\text { "Emerged" }\end{array}$ \\
\hline $\begin{array}{l}\text { Culture, sport } \\
\text { and recreation }\end{array}$ & $195.841=$ & $175.059+$ & \multicolumn{2}{|c|}{$3.388-15.361+$} & \multicolumn{2}{|c|}{$99.285-93.524+$} & 26.994 \\
\hline $\begin{array}{l}\text { Education and } \\
\text { research }\end{array}$ & $15.519=$ & $11.149+$ & \multicolumn{2}{|c|}{$3.135-2.302+$} & \multicolumn{2}{|c|}{$6.293-5.386+$} & 2.630 \\
\hline $\begin{array}{l}\text { Health and } \\
\text { social services }\end{array}$ & $36.013=$ & $26.938+$ & \multicolumn{2}{|c|}{$5.429-5.939+$} & \multicolumn{2}{|c|}{$14.323-10.036+$} & 5.298 \\
\hline $\begin{array}{l}\text { Advocacy and } \\
\text { n.e.c. }\end{array}$ & $53.818=$ & $22.086+$ & \multicolumn{2}{|c|}{$13.292-1.642+$} & \multicolumn{2}{|c|}{$21.550-12.212+$} & 10.744 \\
\hline Total Npos & $301.191=$ & $235.232+$ & \multicolumn{2}{|c|}{$25.244-25.244+$} & \multicolumn{2}{|c|}{$141.451-121.159+$} & 45.666 \\
\hline
\end{tabular}

${ }^{1}$ Own calculations on data provided by Istat

Table 6: Sources of growth of the number of nonprofit organizations between 2001 and 2011, by area of activity.

\begin{tabular}{lllll} 
& Total growth & Sectorial migration & “Natural" growth & "Emerged" \\
\hline $\begin{array}{l}\text { Culture, sport and } \\
\text { recreation }\end{array}$ & $11,9 \%=$ & $-6,8 \%+$ & $3,3 \%+$ & $15,4 \%$ \\
$\begin{array}{l}\text { Education and } \\
\text { research }\end{array}$ & $39,2 \%=$ & $7,5 \%+$ & $8,1 \%+$ & $23,6 \%$ \\
$\begin{array}{l}\text { Health and social } \\
\text { services }\end{array}$ & $33,7 \%=$ & $-1,9 \%+$ & $15,9 \%+$ & $19,7 \%$ \\
$\begin{array}{l}\text { Advocacy and n.e.c. } \\
\text { Total Npos }\end{array}$ & $143,7 \%=$ & $52,7 \%+$ & $42,3 \%+$ & $48,6 \%$ \\
\hline
\end{tabular}

${ }^{1}$ Own calculation on data provided by Istat

Table 5 shows that most Italian Npos remained in the same sector of activity over the period 2001-2011, with less than $9 \%$ of the organizations moving to a different area. On the other hand, entry and exit of organizations, as well as the "emergence" of already existing ones, tend to be very significant in all areas of activities. These trends produced a significant increase in the total number of organizations in all areas of activities (Table 6): advocacy and n.e.c. boast the highest rate of development (more than $140 \%$ ) while other areas show growth rates ranging from $12 \%$ (culture, sports and re-creation) to $39 \%$ (education and research). The contribution of "natural growth" and "emerged" organizations is positive in all areas of activities. On the contrary, the contribution of net sectorial migration is positive only in the areas of education and research, and advocacy and n.e.c. organizations. In particular, our data show a fairly relevant move of organizations from the area of culture, recreation and sport to those of advocacy and n.e.c.

The dynamics of organizations operating in different areas of activity impact on sectorial employment. The sectorial changes in employment, in each area of activity, are described by identity 4): 


$$
\begin{aligned}
& \text { Fte }_{11} \mid R_{11}=\text { Fte }_{01} \mid R_{01}+\Delta \text { Fte }_{01-11} \mid S_{01-11}+\left(\text { Fte }_{11} \mid \mathrm{En}_{01-11}-\text { Fte }_{11} \mid \mathrm{Le}_{01-11}\right)+\left(\text { Fte }_{11} \mid\right. \\
& \left.\mathrm{B}_{01-11}-\text { Fte }_{01} \mid \mathrm{C}_{01-11}\right)+ \text { Fte }_{11} \mid \mathrm{E}_{11}
\end{aligned}
$$

where the variables have the meaning specified earlier, and:

Fte $_{11} \mid \mathrm{En}_{01-11}=$ Fte (in 2011) of the Npos entering the sector between 2001 and 2011,

Fte $_{11} \mid \mathrm{Le}_{01-11}=$ Fte (in 2011) of the Npos leaving the sector between 2001 and 2011.

Table 7, based on identity 4), shows that the growth in employment is heterogeneous in the different areas, with advocacy and n.e.c. growing twice as fast as the total nonprofit sector.

Table 7: Sources of growth of employment in nonprofit organizations between 2001 and 2011, by area of activity.

\begin{tabular}{llllll}
\hline & $\begin{array}{l}\text { Total growth of } \\
\text { Fte 2001-2011 }\end{array}$ & $\begin{array}{l}\text { "Internal } \\
\text { growth" }\end{array}$ & $\begin{array}{l}\text { Sectorial } \\
\text { migration }\end{array}$ & $\begin{array}{l}\text { "Natural" } \\
\text { growth }\end{array}$ & "Emerged" \\
\hline $\begin{array}{l}\text { Culture, sport and } \\
\text { recreation }\end{array}$ & $65,0 \%=$ & $30,9 \%+$ & $-15,6 \%+$ & $27,8 \%+$ & $21,8 \%$ \\
$\begin{array}{l}\text { Education and } \\
\text { research }\end{array}$ & $28,1 \%=$ & $23,9 \%+$ & $-4,8 \%+$ & $-5,5 \%+$ & $14,5 \%$ \\
$\begin{array}{l}\text { Health and social } \\
\text { services }\end{array}$ & $55,4 \%=$ & $35,4 \%+$ & $-7,0 \%+$ & $9,5 \%+$ & $17,5 \%$ \\
$\begin{array}{l}\text { Advocacy and n.e.c. } \\
\text { Total Npos }\end{array}$ & $147,7 \%=$ & $28,8 \%+$ & $64,6 \%+$ & $27,8 \%+$ & $26,6 \%$ \\
\hline
\end{tabular}

${ }^{1}$ Own calculations on data provided by Istat

\begin{tabular}{|c|c|c|c|c|c|c|}
\hline & Fte in 2011 & Fte in 2001 & $\begin{array}{l}\text { "Internal } \\
\text { growth" }\end{array}$ & $\begin{array}{l}\text { Sectorial } \\
\text { migration }\end{array}$ & $\begin{array}{l}\text { "Natural" } \\
\text { growth }\end{array}$ & "Emerged" \\
\hline $\begin{array}{l}\text { Culture, sport and } \\
\text { recreation }\end{array}$ & $180.575=$ & $109.446+$ & $33.810+$ & $\begin{array}{l}8.891- \\
25.922+\end{array}$ & $\begin{array}{l}78.374- \\
47.918+\end{array}$ & 23.894 \\
\hline Education and research & $169.243=$ & $132.153+$ & $31.562+$ & $\begin{array}{l}20.810- \\
27.106+\end{array}$ & $\begin{array}{l}31.757- \\
39.056+\end{array}$ & 19.123 \\
\hline $\begin{array}{l}\text { Health and social } \\
\text { services }\end{array}$ & $441.880=$ & $284.403+$ & $100.687+$ & $\begin{array}{l}62.703- \\
82.501+\end{array}$ & $\begin{array}{l}87.550- \\
60.594+\end{array}$ & 49.632 \\
\hline Advocacy and n.e.c. & $165.426=$ & $66.789+$ & $19.220+$ & $\begin{array}{l}48.294- \\
5.169+\end{array}$ & $\begin{array}{l}36.827- \\
18.278+\end{array}$ & 17.743 \\
\hline Total Npos & $957.124=$ & $592.791+$ & $185.279+$ & $\begin{array}{l}140.698- \\
140.698+\end{array}$ & $\begin{array}{l}234.508- \\
165.846+\end{array}$ & 110.392 \\
\hline
\end{tabular}

Table 8: Employees of nonprofit organizations in 2001 and 2011, by area of activity.

${ }^{1}$ Own calculations on data provided by Istat

In the areas of culture, sport and recreation, as well as in those of health and social services, the growth in the number of employees far exceeds that of the number of organizations. This is the result of various factors: 1) the "internal growth" of organizations that survived through the decade; 2 ) the positive net balance of entry and exit of organizations, and 3) the contribution of the personnel of emerging organizations. On the contrary, both areas loose employees because of the migration of some organizations to other sectors of activity.

In advocacy and n.e.c, the high growth in the number of organizations translates into an equally high growth in employees. This result mainly depends on the positive net sectorial migration rate, but is also supported by the previously described factors. The growth in employment is far smaller (and lower than the growth in the number of organizations) in education and research, where the positive contribution of internal growth is balanced by the negative contributions of sectorial migration and entry and exit of organizations (Table 8). This is the only area in which - despite a positive balance between entry and exit of organizations - the net contribution of the newly born organizations is not enough to balance the negative one of the organizations that stopped their activities. This is, likely, the result of the entry of small organizations (which is quite normal) and the exit of above-average size organizations, a phenomenon less common. 


\subsection{Territorial Change}

Thanks to firm-level panel data, we can also study the entry, exit and emergence of Npos at a local level, analyzing the territorial migration of Italian Npos. To reduce the complexity of our analysis, we only considered the four main geographic areas (GA) or regions (Northwest, Northeast, Central, South and Islands) of our country, and - for each of them - we could say that:

$$
\mathrm{R}_{11}=\mathrm{R}_{01}+\left(\mathrm{EnGA}_{01-11-}-\mathrm{LeGA}_{01-11}\right)+\left(\mathrm{B}_{01-11}-\mathrm{C}_{01-11}\right)+\mathrm{E}_{11},
$$

where the variables have the meaning specified earlier, and:

EnGA $_{01-11}=$ Npos entering the region between 2001 and 2011, and always recorded (in two different areas) in the two censuses;

LeGA $_{01-11}=$ Npos leaving the region between 2001 and 2011, and always recorded (in two different areas) in the two censuses.

Table 9 shows that - over the decade - the growth rates of Npos greatly differed between the main regions of the country. In fact, while organizations located in the North-West and in the Center grew more than the average, those located in the South experienced a much slower pace.

Table 9: Sources of growth of the number of nonprofit organizations between 2001 and 2011, by geographical area.

\begin{tabular}{lllll}
\hline & Total growth & $\begin{array}{l}\text { Territorial } \\
\text { migration }\end{array}$ & "Natural" growth & "Emerged" \\
\hline North-West & $32.4 \%$ & $-0.1 \%$ & $12.5 \%$ & $19.9 \%$ \\
North-East & $27.5 \%$ & $0.1 \%$ & $8.5 \%$ & $18.9 \%$ \\
Center & $32.5 \%$ & $0.1 \%$ & $8.4 \%$ & $20 \%$ \\
South and Islands & $21 \%$ & 0 & $2.2 \%$ & $18.9 \%$ \\
Total Npos & $\mathbf{2 8} \%$ & $\mathbf{0} \%$ & $\mathbf{8 . 6} \%$ & $\mathbf{1 9 . 4} \%$ \\
\hline
\end{tabular}

${ }^{1}$ Own calculations on data provided by Istat

Concerning the determinants of this growth, we observe that Npos did not move much between the different regions of the country, so that the contribution of territorial migration to the growth of the sector in each region is insignificant. Moreover, the impact of the improvement in detection techniques - which led to the emergence of already existing organizations - is positive and quite high, but very similar among the different areas. Consequently, it cannot explain any differences in the growth rate among Italian regions. Finally, we find that entry and exit of Npos are remarkably different in the different areas of the country. The net balance between entry and exit is well above average in the North-West of the country $(+12 \%)$, it is about average in the Central and North-East $(+8 \%)$ regions while it is very low in Southern Italy $(+2 \%)$.

It should be noted (Table 10) that the modest balance between entry and exit of Npos in Southern Italy does not on depend on a low entry rate. On the contrary, the entry rate of Npos in that region is the second highest in the country, after Central Italy. Nonetheless, the exit rate is also extra-ordinarily high, and it explains the overall modest growth.

Table 10: Nonprofit organizations in 2001 and 2011, by geographical area.

\begin{tabular}{|c|c|c|c|c|c|}
\hline & Npos in 2011 & Npos in 2001 & $\begin{array}{l}\text { Territorial } \\
\text { migration }\end{array}$ & $\begin{array}{l}\text { "Natural" } \\
\text { growth }\end{array}$ & "Emerged" \\
\hline North-West & $82.883=$ & $62.590+$ & $148-197+$ & $\begin{array}{l}\begin{array}{l}36.162-28.316 \\
+\end{array}\end{array}$ & 12.496 \\
\hline North-East & $74.314=$ & $58.292+$ & $170-125+$ & $\begin{array}{l}30.424-25.479 \\
+\end{array}$ & 11.032 \\
\hline Center & $64.677=$ & $48.810+$ & $245-212+$ & $\begin{array}{l}32.076-26.017 \\
+\end{array}$ & 9.775 \\
\hline South and Islands & $79.317=$ & $65.540+$ & $77-106+$ & $\begin{array}{l}42.789-41.346 \\
+\end{array}$ & 12.363 \\
\hline Total Npos & $301.191=$ & $235.232+$ & $640-640+$ & $\begin{array}{l}\text { 141.451-121.159 } \\
+\end{array}$ & 45.666 \\
\hline
\end{tabular}

${ }^{1}$ Own calculations on data provided by Istat 
The different dynamics of the Npos carry consequences on the employment level of the sector in the various geographical regions. We can analyze different trends using the following identity:

$$
\begin{aligned}
& \text { Fte }_{11} \mid R_{11}=\text { Fte }_{01} \mid R_{01}+\Delta \text { Fte }_{01-11} \mid S_{01-11}+\left(\text { Fte }_{11} \mid \text { EnGA }_{01-11}-\text { Fte }_{11} \mid \text { LeGa }_{01-11}\right)+\left(\text { Fte }_{11} \mid\right. \\
& \left.\mathrm{B}_{01-11}-\text { Fte }_{01} \mid \mathrm{C}_{01-11}\right)+ \text { Fte }_{11} \mid E_{11}
\end{aligned}
$$

where:

Fte $_{11} \mid$ EnGA $_{01-11}=$ Fte (in 2011) of the Npos entering the region between 2001 and 2011,

Fte $_{11} \mid$ LeGA $_{01-11}=$ Fte (in 2011) of the Npos leaving the region between 2001 and 2011.

Table 11 and Table 12 emphasize that the growth rate of employment is significantly higher than average in the North of the country (especially in the North-East), while the Central, and particularly the Southern part of Italy experienced positive, but modest growth rates. The contribution to the total growth of employment given by those Npos that were detected thanks to improved techniques is very homogeneous between the different geographical areas. Therefore, differences in overall growth rates in employment are explained by the internal growth rate (particularly high in the North-East, and particularly low in the South), by the balance between entry and exit of organizations (high in Northern Italy, but below average in the central and southern part of the country) and, finally, by the "migration" of organizations, which contributes significantly to the growth of organizations located in the central regions of Italy.

\begin{tabular}{|c|c|c|c|c|c|}
\hline & $\begin{array}{l}\text { Total growth of Fte } \\
2001-2011\end{array}$ & "Internal growth" & $\begin{array}{l}\text { Geographical } \\
\text { migration }\end{array}$ & "Natural" growth & "Emerged" \\
\hline North-West & $64,6 \%=$ & $31,1 \%+$ & $-2,5 \%+$ & $16,2 \%+$ & $19,8 \%$ \\
\hline North-East & $77,6 \%=$ & $45,6 \%+$ & $0,3 \%+$ & $14,7 \%+$ & $17,1 \%$ \\
\hline Center & $57,3 \%=$ & $29,8 \%+$ & $3,8 \%+$ & $5,7 \%+$ & $18,1 \%$ \\
\hline $\begin{array}{l}\text { South and } \\
\text { Islands }\end{array}$ & $45,3 \%=$ & $19,1 \%+$ & $-0,5 \%+$ & $7,7 \%+$ & $18,9 \%$ \\
\hline Total Npos & $61,5 \%=$ & $31,3 \%+$ & $0,0 \%+$ & $11,6 \%+$ & $18,6 \%$ \\
\hline
\end{tabular}

Table 11: Sources of growth of employment in nonprofit organizations between 2001 and 2011, by geographical area.

${ }^{1}$ Own calculations on data provide by Istat

Table 12: Employees of nonprofit organizations in 2001 and 2011, by geographical area.

\begin{tabular}{lllllll}
\hline & Fte in 2011 & Fte in 2001 & $\begin{array}{l}\text { “Internal } \\
\text { growth" }\end{array}$ & $\begin{array}{l}\text { Geographical } \\
\text { migration }\end{array}$ & "Natural" growth & "Emerged" \\
\hline North-West & $328.633=$ & $199.711+$ & $62.052+$ & $756-5.682+$ & $78.028-45.676+$ & 39.444 \\
North-East & $224.461=$ & $126.353+$ & $57.564+$ & $827-428+$ & $45.898-27.333+$ & 21.640 \\
Center & $216.497=$ & $137.652+$ & $40.967+$ & $7.060-1.947+$ & $48.636-40.849+$ & 24.918 \\
South and Islands & $187.533=$ & $129.075+$ & $24.696+$ & $1.372-1.958+$ & $61.946-51.988+$ & 24.390 \\
Total Npos & $957.124=$ & $592.791+$ & $185.279+$ & $10.015-10.015$ & $234.508-165.846+$ & 110.392 \\
& & & & + & & \\
\hline
\end{tabular}

${ }^{1}$ Own calculations on data provide by Istat

These data add new suggestions to the long-term debate about the relative economic and social underdevelopment of the Southern part of the country (compared to the Northern one). Following the classic interpretation of Putnam (1993), the relative under-development could depend on poor political institutions, and the latter could be influenced by the low quality of civic life (from voters turn-out to membership in associations). Our data show that Southern citizen are at least as willing and able to create new Npos as their Northern counterparts. What really makes the difference is the capacity of these new organizations to survive and thrive over time. Therefore, the environment (and its impact on the Npos) appears to play a relevant role in determining the success of the sector. In this respect, the relationship between public administrations (at the local level) and nonprofit service providers should be analyzed. This relationship could follow different patterns: supplementary, complementary or adversarial (Young 2000b). We already mentioned the complementary role developed by public entities and Npos starting in the Nineties. This was a common trend all over the country. Nonetheless, in the North (and the Center) the quality of public administrations was higher, and institutions were better run compared to the South. Therefore, public administrations in the North could rely on higher lev- 
els of economic resources, and on higher efficiency in their use; these resources could be used to buy services from Npos. Therefore, it looks as if Putnam's classic relation should be reversed: the poor quality of public administrations has a negative impact on the nonprofit sector.

\section{Concluding Remarks}

During the decade 2001-2011, the Italian nonprofit sector has certainly experienced a season characterized by high growth in both the number of organizations and in their employment levels. However, the new availability of census firm-level panel data allows us to observe that a relevant part of this growth (about $70 \%$ of the increase in the number of organizations, and $30 \%$ of the increase in employment) should be attributed to the improvement of detection techniques adopted by the Italian statistical office. In 2011, Istat was able to trace organizations that - although already existing in 2001 - had, for various reasons, not been recorded among the active ones on that year's census. When considering this fact, the growth in the number of organizations - over the decade - goes from $28 \%$ to just over $7 \%$, and the growth in employment from $61 \%$ to $36 \%$.

Beyond that, firm-level panel data lead to observe that the creation of an extremely high number of new Npos over the decade has gone together with an almost equally high number of organizations leaving the sector or stopping their activities altogether. This is quite far from what was observed in the US context in the past (Harrison and Laincz 2008), while no comparable information is available in Europe. The balance between the two trends - although positive - appears quite modest. Therefore, the net contribution of entry and exit of Npos to the creation of new employment in the sector is rather modest. In fact, the jump in employment in the sector mainly depends on the internal growth of organizations that were already active at the beginning of the decade.

The policy maker should consider both factors: the sector grew, but its growth was not as explosive as it appears at first sight, so that its activities should be further supported. Most likely, the best way to facilitate the growth of this sector is to take care of those organizations that already exist, sustaining their activities, besides facilitating the creation of new institutions. Moreover, beside facilitating and giving incentives to new Npos, the government should focus on policies that could contribute to building their capacities (in fields such as strategic planning, financial and organizational management, communication, etc.), so that the relevant efforts put by citizens in creating new organizations are not wasted because of their failure to persist over time.

Beyond that, the data show that the sector is characterized by deep internal cracks that run through sectors of activity and geographical regions. It should be underlined that, in Southern Italy, the remarkable ability to create new nonprofit organizations does not match with a corresponding ability to make them survive over the years.

\section{Notes}

1 For a seminal analysis of the interdependence between the nonprofit and the business sector of the economy, see Rudney and Young (1989).

2 In a nearby field, some scholars analyzed the entry and exit of employees; a few focused on the movement from the nonprofit to the forprofit sector (Kang et al. 2015), while quite many scholars focused on the opposite movement (see e. g. Benz 2005; Freund 2005; Becchetti, Castriota, and Depedri 2014). We will not focus on this area of analysis.

3 This is not a precise estimate of the bias in 2001 census. In fact, some organization active in 2001 and not recorded at the time could have exit the sector before 2011.

4 Calculated as follows: $\left(\mathrm{B}_{01-11}+\mathrm{C}_{01-11}\right) / \mathrm{R}_{01}$.

\section{References}

Andersson, F.O., and M.R. Ford. 2016. “Social Entrepreneurship through an Organizational Ecology Lens: Examining the Emergence and Evolution of the Voucher School Population in Milwaukee." Voluntas 27 (4): 1760-80.

Anheier, H.K. 2005. Nonprofit Organizations. Theory, Management, Policy. New York, NY: Routledge.

Anheier, H.K., and L.M. Salamon. 2006. "The Nonprofit Sectsor in Comparative Perspective." In The Nonprofit Sector. A Research Handbook, 2nd ed, edited by W.W. Powell and R. Steinberg, 89-113. New Haven, CT: Yale University Press.

Anheier, H.K., and W. Seibel. 2001. The Nonprofit Sector in Germany. Manchester, UK: Manchester University Press.

Archambault, E. 1997. The Nonprofit Sector in France. Manchester, UK: Manchester University Press.

Archambault, E., E. Priller, and A. Zimmer. 2014. “European Civil Societies Compared: Typically Cerman-Typically French?.” Voluntas 25 (2): 514-37. 
Barbetta, G.P., ed. 1997. The Nonprofit Sector in Italy. Manchester, UK: Manchester University Press.

Barbetta, G.P., A. Mancini, and F. Lorenzini. 2016. "Il settore nonprofit italiano. Dieci anni di sviluppo nei dati censuari." In Le istituzioni nonprofit in Italia. Dieci anni dopo, edited by G.P. Barbetta, G. Ecchia and N. Zamaro, 25-56. Bologna, Italy: II Mulino.

Becchetti, L., S. Castriota, and S. Depedri. 2014. “Working in the For-Profit versus Not-For-Profit Sector: What Difference Does It Make? an Inquiry on Preferences of Voluntary and Involuntary Movers." Industrial and Corporate Change 23 (4): 1087-120.

Benz, M. 2005. "Not for the Profit, but for the Satisfaction? Evidence on Worker Well-Being in Non-Profit Firms." Kyklos 58: 155-76.

Casey, J. 2016. "Comparing Nonprofit Sectors around the World. What Do We Know and How Do We Know It?." Journal of Nonprofit Education and Leadership 6 (3): 187-223.

Corbin, J.J. 1999. “A Study of Factors Influencing the Crowth of Nonprofits in Social Services." Nonprofit and Voluntary Sector Quarterly 28 (3): 296-314.

Dietz, N., P. Barber, C. Lott, and M. Shelly. 2017. “Exploring the Relationship between State Charitable Solicitation Regulations and Fundraising Performance." Nonprofit Policy Forum 8 (2): 183-204.

Freund, A. 2005. "Commitment and Job Satisfaction as Predictors of Turnover Intentions among Welfare Workers." Administration in Social Work 29 (2): 5-21.

Galera, G., and C. Borzaga. 2009. "Social Enterprise: An International Overview of Its Conceptual Evolution and Legal Implementation." Social Enterprise Journal 5 (3): 210-28.

Gayle, P.C., T.D. Harrison, and J. Thornton. 2017. “Entry, Donor Market Size, and Competitive Conduct among Nonprofit Firms." International Journal of Industrial Organization 50: 294-318.

Hansmann, H. 1980. “The Role of Nonprofit Enterprise." Yale Law Journal 89 (5): 835-901.

Hansmann, H. 1987. "The Effect of Tax Exemption and Other Factors on the Market Share of Nonprofit versus For-Profit Firms." National Tax Journal 40 (1): 71-82.

Harrison, T.D., and C.A. Laincz. 2008. "Entry and Exit in the Nonprofit Sector." The B.E. Journal of Economic Analysis and Policy 8 (1): 1-41.

Harrison, T.D., and J. Thornton. 2014. "Too Many Nonprofits? an Empirical Approach to Estimating Trends in Nonprofit Demand Density." Nonprofit Policy Forum 5 (2): 213-29.

Istat. Istituzioni nonprofit in Italia Rome, Italy: Collana Informazioni, Istat

Istat. 2004. "Ottavo censimento generale dell'industria e dei servizi." http://dwcis.istat.it/cis/index.htm.

Istat. 2014. “Nono censimento generale dell'industria e dei servizi." http://dati-censimentoindustriaeservizi.istat.it/Index.aspx.

James, E., and S. Rose-Ackerman. 1986. The Nonprofit Enterprise in Market Economies, Chur, Switzerland: Harwood Academic Publishers

Kang, C., S. Huh, S. Cho, and E. Y. Auh. 2015. “Turnover and Retention in Nonprofit Employment: The Korean College Craduates' Experience." Nonprofit and Voluntary Sector Quarterly 44 (4): 641-64.

Kendall, J., and M. Knapp. 1996. The Voluntary Sector in the UK. Manchester, UK: Manchester University Press.

Kuti, E. 1996. The Nonprofit Sector in Hungary. Manchester, UK: Manchester University Press

Lecy, J.D., and D.M. Van Slyke. 2013. “Nonprofit Sector Growth and Density: Testing Theories of Covernment Support." Journal of Public Administration Research and Theory 23 (1): 189-214.

List, J.A. 2011. "The Market for Charitable Giving." Journal of Economic Perspectives 25 (2): 157-80.

Matsunaga, Y., and N. Yamauchi. 2004. "Is the Government Failure Theory Still Relevant? A Panel Analysis Using US State Level Data." Annals of Public and Cooperative Economics 75 (2): 227-63.

Oecd. Job Creation through the Social Economy and Social Entrepreneurship Paris, France: Oecd Press

Pettijohn, S.L. 2013. The Nonprofit Sector in Brief: Public Charities, Giving and Volunteering-2013. Washington, D.C.: Urban Institute.

Putnam, R. 1993. Making Democracy Work. Civic Traditions in Modern Italy. Princeton, N]: Princeton University Press.

Rose-Ackerman, S. 1982. "Charitable Giving and 'Excessive' Fundraising." Quarterly Journal of Economics 97: 193-212.

Rudney, G., and P. Young. 1989. “The Nonprofit Sector of the U.S. Economy: A Methodological Statement." Review of Income and Wealth 35 (1): $57-80$.

Salamon, L.M., and H.K. Anheier. 1996. The Emerging Nonprofit Sector. An Overview. Manchester, UK: Manchester University Press.

Salamon, L.M., and H.K. Anheier. 1998. "Social Origins of Civil Society: Explaining the Nonprofit Sector Cross-Nationally." Voluntas 9: 213-48.

Salamon, L.M., S.W. Sokolowki, and H.K. Anheier 2000. "Social Origin of Civil Society: An Overview." Working papers of the Johns Hopkins comparative nonprofit sector project.

Schiff, J., and B. Weisbrod. 1993. "Competition between For-Profit and Non-Profit Organizations." In The Non-Profit Sector in the Mixed Economy, edited by A. Ben-Ner and B. Gui. Ann Arbor: The University of Michigan Press.

Sivesind, K.H., H. Lorenten, P. Selle, and D. Wollebaek. 2002. The Voluntary Sector in Norway. Composition, Changes and Causes. Oslo, Norway: ISAF.

Thomas, A. 2004. "The Rise of Social Cooperatives in Italy." Voluntas 15: 243-63.

Twombly, E.C. 2002. "Organizational Response in a Era of Welfare Reform: Exit and Entry Patterns of Human Service Providers." Nonprofit and Voluntary Sector Quarterly 31 (4): 597-8.

Twombly, E.C. 2003. “What Factors Affect the Entry and Exit of Nonprofit Human Service Organizations in Metropolitan Areas?." Nonprofit and Voluntary Sector Quarterly 32 (2): 211-35.

Weisbrod, B. A. 1977. The Voluntary Nonprofit Sector. Lexington, MA: Lexington Books.

Wijkstrom, F., and T. Lundstrom. 1997. The Nonprofit Sector in Sweden. Manchester UK: Manchester University Press.

Wijkstrom, F., and A. Zimmer. 2011. "Introduction: Nordic Civil Societies beyond Membership and Movements," in Nordic Civil Society at a Cross-Roads, edited by F. Wijkstrom, and A. Zimmer. Baden-Baden, Cermany: Nomos eLibrary

Yamamoto, T. 1998. The Nonprofit Sector in Japan. Manchester UK: Manchester University Press.

Young, D.R. 2000a. "Government Failure Theory." In The Nature of the Nonprofit Sector, edited by J.S. Ott, 119-37. Boulder, CO: Westview.

Young, D.R. 2000b. "Alternative Models of Government-Nonprofit Sector Relations: Theoretical and International Perspectives." Nonprofit and Voluntary Sector Quarterly 29 (1): 149-72. 